\title{
Then and Now
}

\author{
By MARION NIXON, Wauchope, Sask.
}

Our pioneer childhood lives vividly as a series of pictures stamped on the retina of the mind. To compile this article linking the then and now, I have visited my particular gallery of memories which chances to go back exactly five prairie years. We came from Ontario in May, 1904, a year after Dad and the eldest brother came west to take up land. We drove in a democrat 40 miles suth from Indian Head across raw prairie, past the hilly country of lovely Lake Marguerite where the men had cut poplar poles to frame our soddy stable, over miles of flat land whereon lay gleaming lakes of shallow water, down and up the precipitous slopes of the Nianybone Creek (source water of the Wascana) avoiding the equally steep crossing of its little tributary closer to our home, which later seemed such a place of romance; in a cup between steep little hills lay a year-round waterhole fed by a welling spring, the north bank surmounted by a much used Indian campsite marked by many rings of tent-pegging stones, while high, lone and austere on the opposite hilltop, overlooking all the surrounding country was a rough cairn of field stones, memorial it would seem over some important grave.

Of that drive I have no memory except one induced by Mother's oft repeated description of our journey into the new land. My actual pioneer memory is of watching a prairie schooner's white canvas glistening against the sunset as a storekeeper freighted in goods to the new townsite 3 miles south of our farm. And that was 1905 .

Of the next seven years, when we lived in the shack, my memories are mostly of outdoors and animals, wild or tame, of birds and flowers that still carry in familiar use the names we gave them then ... "policeman's hat" for shooting star, "Stewart's Favorite" for the salmon pink mallow nestling on green-grey leaves in a hot sandy spot, "running daisies" for the flaunting gaillardia of the roadside because on a family walk we three youngest would race to the next flower, thus marking it our own, never allowed to pick flowers on the walk away from home lest they wilt, and only enough for a proper bouquet on the way back. So did our parents instill the principles of conservation even in the beginning, though Nature seemed most bounteous with her blossoms.

The bleached bones of buffalo were a common sight, and we had a collection of the stubby, sharp, curved horns from skulls that were found. We loved to play where deep trodden paths led in, like spokes from the prairie, to a buffalo wallow whose hub was a glacial boulder. Here, on spongy ground by a slough they had trampled a round trough as they pushed and jostled to rub head and horn and shoulder against the stone, loosening mud-caked coats of their itchiness in spring. The sloping tlat top of that stone made us an island in the circular pond; its edges are to this day glazed by the annual rubbing of many heads. On the large slough nearby we could watch "helldivers" (grebes) and many ducks, and once a flock of pelicans in migration.

Most familiar animal was the flickertail gopher that popped up everywhere, and his rarer cousin the striped gopher. The first, (we know it as Richardson's ground squirrel now) lived either in separate burrows or in a community "gopher knoll" riddled with passageways and heaped up outlets. Many of these showed evidence of being dug into by badgers at various times, the openings expanded but their contours softened again by the dirt of more recent excavation.

Such gopher knolls often had other residents ... garter snakes by the dozen out and squirming in spring sun; or a family of burrowing owls, the old owl rigid and still above the opening as any gopher owner had been, and as ready to pop downward at the too close approach of an enemy. I have not seen a burrowing owl for over 20 years. Too often they could find, in later years, an 
authentic gophersite only on virgin prairie by a roadside, misjudged time to move when a car came along, and so died out.

It was on such close-nibbled gopher mounds, warm and dry to lie upon on spring days, that we found the first furry crocus buds; a stone turned over would discover to us a world of ants or beetles; or, arm raised against the sun, we would watch the slowly swirling flocks of cranes and listen to their ventriloquistic cronkings.

I cannot remember antelope, but they were there till the winter of disastrous blizzard, 1906-7. We often saw slinking coyotes and heard their wierd keening in the night. I, it was, who saw the fox, and was as proud that Dad trusted my description as I was of my first "first sight" record; but that "first sight" has left till now the authentic glow of spirit which the amateur naturalist counts as full reward!

About that time, they tell me, I also proved one spring that I had seen the first hawk. I hotly denied it was a crow! Its wings went thus ... and I beat my arms lazily, then tilted and swayed them as though soaring. The point was conceded.

Gophers we snared, trapped, shot or pcisoned, they were so destructive of the precious sprouts of grain; but we never could keep wild things as pets lest their natural wit be dulled by trust and easy living, dice loaded against them when turned loose to contend with normal hardship and foes again.

Through those years I craved a book such as the Field Guides we have now, to tell me the name of the wee sparrow nesting in a mossy cup by a slough where a cow had stepped in wet weather, or the difference between a blackbird with red epaulets and the one with white on the wings.

Such a book I never found till, as a teacher, I moved to this poplar dotted country east of Moose Mountains. Here I first knew wild fruit other than strawberries, met our lily emblem in abundance, was charmed by the gold-kid slippers of our wild orchid, the flash of gaudy orioles through the trees and learned songs of vireo and warbler.
Other woodpeckers than the flicker that followed telephone lines across the prairie tap on my trees. Great blue herons fish the Antler Creek, and we are apt to see a porcupine lumbering among the willows. White tailed deer are common and beavers in a few years have reached pest proportion. While plain birds such as the lark bunting (of the white epaulet) have vacated our bluffy terrain the chickadee has become a familiar sprite. Yet fifty years ago this country was still burnt clean as any western plain, with "not even a sapling big enough for a whip" as one pioneer assured me.

Nature has proven that though drought came, there have been years of excessive rainfall and deep sloughs since. The sweep of devastating fires retired into past history with cultivation of the land. Wildlife populations have changed with the increase of parkland habitat and the use of land by man. It is all part of the inevitable change due to civilization.

We may deplore the loss of natural growth in our home acres. All we can do is, each of us, to refrain from destroying it further on untilled land. We should remember the pioneer adage, "a penny saved is a penny gained." That is the only way we can keep enough "seed," be it bird or beast or flower, to assure that future generations of our children will know the Saskatchewan, even a little, to which we came.

\section{Winter Birds at Nipawin}

Anne Matthews of Nipawin reports a good winter for birds, with Redpolls and Evening Grosbeaks especially numerous at the banding station, and lots of Ravens about. Her brother banded over 800 Redpolls and 67 Evening Grosbeaks this winter. $\mathrm{He}$ caught one Evening Grosbeak that had been banded at Marquette, Michigan, and another that had been banded at Madison, Wisconsin.

One short-eared Owl was seen by the Matthews February 13, and 4 more a few days later by Maurice Street. This posed the question of whether the owls were migrating very early or had stayed all winter to feed on the hundreds of mice. 